\title{
African-Centered Multicultural Art Education: An Alternative Curriculum and Pedagogy
}

\section{Samuel Adu-Poku}

For far too long, art history and art education in Euro-Canadian/American society have been neglectful of the artistic traditions of its minority students (Chalmers, 1996; DePillars, 1990). Blacks and children of non-European ancestry are often miseducated, or left at the margins of school curricula. Nevertheless, theories advanced to explain the causes of educational underachievement of Blacks and children from ethnic minority backgrounds (i.e., Bereiter \& Englemann, 1966) tend to blame the victim while ignoring the complex interrelationship between economic, social, cultural, political and educational factors contributing to school failure. Ogbu (1986) and Nieto (1996) talk about the cultural incongruencies between the home and the school, and explain that it is the school's perception of minority students' values, skills, expectations, language, art, culture, history, race, ethnicity, and class as inadequate and negative, and the subsequent devalued status of these characteristics in the academic environment, that help to explain school failure. Proponents of multicultural education (e.g., Asante, 1991, Chalmers, 1996; Nieto, 1996) assert that Eurocentric education is inadequate in preparing students to function in a democratic/pluralistic society, and in an employment market that is increasingly oriented toward the cultural diversity of our rapidly shrinking world (a global village). With Canada's long standing policy of multiculturalism, and the increasing ethno-cultural diversity of its classrooms, it is imperative for art teachers and educators to reexamine curricula, textbooks and teaching methodologies to provide a more accurate and comprehensive art education for all students that form the mosaic of Canadian society.

Over the years, various models of multicultural education have been advanced in Canada. McLeod (1992) however, identifies three approaches to multicultural education practised in Canada namely: problem oriented, cultural/intercultural, and ethnic specific/single group studies. A problemoriented approach involves proactive and reactive programs that help immigrants to adapt to Canadian society and to respond to issues of racism and other forms of inequality. The cultural/intercultural model promotes education for cultural pluralism. The ethnic specific/single group studies approach to multicultural education seeks to raise people's consciousness concerning an identified group by teaching both its members and all others about the history, culture and contributions of that group, and how that group relates with the dominant group in society. Because of past omission and philosophical bias in curriculum choices, some ethnocultural groups in Canada have established separate school programs. These include the Ukrainian and Mennonite schools in Alberta, Chinese, Hebrew and Greek schools in Ontario and Quebec, and Punjabi and Hebrew schools in British Columbia (Moodley, 1995). The African-Canadian community in Vancouver is an emerging group that has been searching for ways to provide their children with culturally relevant programs to enrich their artistic, cultural and educational experience. As a volunteer to this group, I have worked 
with the community on several programs: as an organizer and facilitator of the parent group discussions, and an art and cultural educator for the youth at the Multicultural Family Center (MFC) in Vancouver. During our work, we identified some cultural gap in the education of the Black children and initiated programs with the aim of addressing their cultural needs. My dissertation topic has evolved through my encounter with the African-Canadian community in Vancouver.

\section{Statement of the Problem}

Many Canadian teachers and educators, because of their training, experiences, values and professional backgrounds, may be predisposed to Eurocentric and modernist perspectives. They may therefore, express some reluctance to the curriculum mainstreaming of African-centered art and knowledge, or any other cultural traditions they ideologically oppose. Besides, those art educators who are genuinely interested in infusing multicultural objectives into their disciplines may not have a clear understanding of multicultural education: how it is defined; how it is implemented; the possible sources of content and pedagogy; its tension points and places; its effects on students; and what such an infusion means for their curriculum field. Because of these tensions and dilemmas, many Black/African-Canadian students in Vancouver schools have remained separated from their history and culture. Meanwhile, inquiries into the differences in aesthetic perceptions of ethnic groups (Irwin \& Farrell, 1996; Neperud, Serlin \& Jenkins, 1986) have established that most ethnic groups possess aesthetic values central to their culture. Therefore, depriving minority students of the knowledge of their art and culture in the curriculum is detrimental not only to their artistic and academic development but also to their self-image.

This study explores ways to improve Black/African-Canadian students' cultural awareness and self-image, as well as promote healthy inter-group relations among students of diverse backgrounds in Vancouver. The study is an attempt to fill-in the gaps in: the conceptualization of art curricula; the cultural education of Black children; and the research on Black students and African immigrants in the Greater Vancouver Regional District.

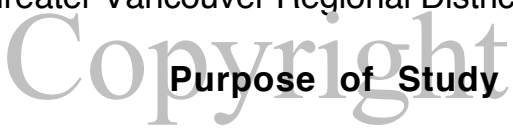

My research involves the development and implementation of a community-based model of an African-centered multicultural art curriculum. It has two main goals. First, as a background to the development of the curriculum, I examine the cultural and educational barriers to Black/African-Canadian students' participation and attainment in art and education in Vancouver, and its implications. A major reason why multicultural education has been criticized as the production of passive consciousness of culture (Banks, 1992; Solomon \& Levine-Rasky, 1996), and subject to different interpretations is that the construct has not been adequately grounded in a causal analysis of school failure among subordinated group students (Nieto, 1996). Understanding the realities of Black/African Canadian children's educational experience in Canada is therefore crucial for any effective educational policies sympathetic to their needs. 
The second purpose is to develop and implement a collaborative Africancentered multicultural art curriculum, as well as investigate its effects of on:

(1) Black students' attitudes and self-concepts as they unfold at the MFC; and (2) students of diverse backgrounds at the John Norquay Elementary School art classroom. As part of the study, I will document the process of doing communitybased participatory research as it unfolds with the research. Community-based participatory research suggests a way in which communities without socio-political power can use research to support their struggle for self-determination by gaining control of information that can influence decisions regarding their lives (Bopp \& Bopp, 1985; Stull \& Schensul, 1987).

\section{Research Questions}

The following questions will be addressed by the study:

1. In what ways do school curricula, and the general school organization influence Black/African-Canadian children's participation and attainment in art and education?

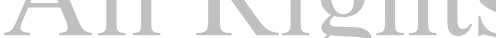

2. What are the possible sources of content and teaching methodology for an African-centered multicultural art curriculum?

3. How do Black/African-Canadian children react to the African art and cultural education project at the Multicultural Family Center?

4. What are the process and nature of doing community-based participatory research as it unfolds with the curriculum advisory team?

5. What is the impact of an African-centered multicultural art program on children at the John Norquay Elementary School?

\section{Methodology}

Scholars of Africa and the diaspora have long sought for new theoretical frameworks that would afford an accurate and fuller insight into the political, economic and social dynamics of the continent and its people. One of the most intellectually stimulating and innovative concepts that has emerged in the scholarship on African peoples within the last two decades is "Africentricity" (Afrocentricity) ${ }^{1}$. Africentricity means placing African ideals at the center of our approach to problem solving or, any analysis that involves African culture and behaviours (Asante, 1987). My methodology is influenced by the Africentric

${ }^{1}$ Although "Afrocentricity" has been used by many Black scholars including Asante (1980), who is credited for developing the Afrocentric paradigm, the researcher views the term "Africentricity" as more explicit concept that does not repeat the "Afro" prefix which has generated quite a lot of discussion among Americans of African descent. 
conceptual framework. The underlying assumption in this study is that students of African descent are in a stronger position to learn if they are placed at the center rather than at the margin of school curriculum and pedagogy.

\section{Africentricity (Afrocentricity)}

The Africentric paradigm holds that "any meaningful and authentic study of peoples of African descent must begin and proceed with Africa as the center, not periphery; as subject, not object" (Abarry, 1990, p. 123). It insists, for example, that the ancient Kemetic (Egyptian) civilization should be the classical reference point for the study of African civilization, as the Greek civilization is for analysis of European civilization (Diop, 1974). The main thrust of Africentric project is to liberate the research and study of African peoples from the hegemony of Eurocentric scholarship and thus, assert a valid worldview through which Blacks/African peoples can be studied objectively. Africentrists see African-Canadian or African American experience as a dimension of African history and culture which cannot be separated from its past. It allows one to see oneself as a conscious being with a history. In the United States, Afrocentricity has received the most attention in primary and secondary education (Schiele, 1991) where it has been largely associated with the exposure of African-American and others to the historical accomplishments of people of African descent.

Africentrists recognize the validity of other non-hegemonic perspectives - Asia-centered, Aboriginal-centered, America-centered and even Europecentered in its nonhegemonic forms. Africentrists have argued cogently that the acceptance and recognition of all perspectives is far more likely to lead to genuine human knowledge and inter-cultural understanding than reliance on one absolute worldview. In Asante's (1988) formulation, Africentricity is a way of life, ungirded by a value system and a religious orientation that differ from Eurocentricity in its conception of human beings.

Afrocentricity has a distinct set of cosmological, ontological epistemological and axiological attributes. Cosmologically, the Africentric model views the structure of reality from a perspective of interdependency. That is, all elements of the universe such as humans, animals, inanimate objects, spiritual beings, and so forth are perceived as interconnected (Bell et al., 1990). There is no separation between the spiritual and the material. Therefore, to destroy one component of the web of cosmic elements is to destroy the entire universe. Ontologically, Africentricity assumes that all elements of the universe, including humans, are spiritual - that is, they are created from a similar universal substance (Akbar, 1984). Spirituality in this instance implies the invisible or nonmaterial substance that connects all elements of the universe. Epistemologically, the construct places considerable emphasis on an affective way of obtaining knowledge (Akbar, 1984; Asante, 1988; Schiele, 1991). That is, from an Africentric standpoint, knowing (i.e., understanding events and reality) through emotion or feeling is considered valid and critical. The focus on affective way of knowing does not imply a rejection of rationality. Rather, affect assumes preeminence as a means of knowing. Axiologically, Africentricity significantly underscores the value of interpersonal relationships: group unity, mutuality,

Marilyn Zurmuehlen's Working Papers In Art Education 1998-1999 
collective responsibility, community and social bonding. This emphasis fosters a human centered perspective toward life rather than an object or material perspective in which the value in maintaining and strengthening interpersonal bonds supersedes the concern over acquiring material objects and accumulating wealth (Schiele, 1994).

The Africentric research method is eclectic. It embraces several approaches to studying phenomena. For instance, the liberatory tenet of participatory research, feminist research and critical ethnography coincides with the Africentric framework. Despite its eclectic approach, Africentric scholars are not yet agreed on the role that, for instance, White feminism or Marxism can play in Africentric discourse. This is so because, as products of Eurocentric consciousness, these theories exclude the historical and cultural perspectives of Africa. As a theory therefore, Africentricity is undoubtedly still in an evolutionary process. The Africentric method rejects the hierarchical relationship between an investigator and subjects. It speaks of research that is ultimately verifiable in the experiences of human beings, as the ultimate empirical authority. The methods of proof are grounded upon the principles of fairness and openness. Asante (1990) points out that:

The Africentrist seeks to uncover and use codes, paradigms, symbols, motifs, myths, and circles of discussion that reinforce the centrality of African ideals and values as a valid frame of reference for acquiring and examining data. Such a method appears to ... re-valorize the African place in the interpretation of Africans, continental and diasporan. (p. 6)

Africentricity involves the dual-collection model, with at least one researcher from the sociocultural context, in order to deal with problem of bias and misrepresentation particularly as it relates to cross-cultural research. In this effect this research will employ a research assistant to collect and assess similar data. Besides the dual-collection model, the study will employ triangulation of information and in-depth interviews. This approach is contrasted with the experimental framework which is based on the logic of manipulation of variables and prediction. It also suggests cultural and social immersion as opposed to scientific distance as a valid approach to naturalistic research. In this sense, my identity as an insider provides a rich contextual setting. My socialization and training provide me with the advantage of knowing the history, language, philosophy, values, and myths about the people under study.

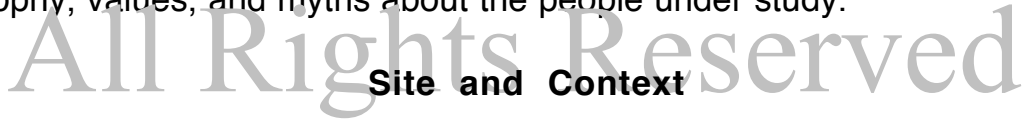

The principal sites for this study are the Multicultural Family Center (MFC) and John Norquay Elementary School. The MFC is located within the Britannia Community Center in East Vancouver. It is here that some members of Black/African-Canadian residents from Vancouver and its surrounding districts converge frequently to participate in sociocultural programs organized by the MFC to support Black parents and their children. The surrounding communities consist of many ethnic groups and cultures: Asians, Indians, Latinos, Blacks and other minorities. Participants for this study will be selected from members of the

Marilyn Zurmuehlen's Working Papers In Art Education 1998-1999 
Black/African community who patronize the activities at the MFC. John Norquay Elementary is an inner city school with a large population of ethnic minority children.

A curriculum advisory team comprising the staff of the MFC, five Black/African parents, a curriculum consultant, a high school art teacher and the researcher was set up to provide advice on the appropriate content and methodology for the African-centered multicultural art project. The first meeting with the curriculum advisory team took place in November, 1997 during which the researcher discussed the focus of the study and the role of the advisory team.

\section{Data Collection}

Data for the study has been generated through the implementation of the African art and cultural program. In all, 25 children between the ages of 10 and 18 years participated in the program, but 15 children who could provide informed consent, and met the demands of the research were interviewed. At the second site, John Norquay School, 30 Grade 7 students of diverse backgrounds will participate in the art program and the study. The art teacher and school principal will be interviewed.

The goal of the interviews is not only to shed light on the artistic, educational and cultural experience of the children from the African-Canadian community in Vancouver, but also to obtain the perspective of individual participants regarding their perceptions about the African art and cultural program at the MFC. The interview questions are open-ended. This approach allows the researcher to review questions in the course of data collection and analysis so as to provide adequate answers to the main questions in the study. Two research methods were employed: focus group interviews with students took a maximum of 45 minutes, following the completion of the lessons; and 45 minutes individualized interviews with students, parents, art teacher, school principal, and MFC staff. A second round of interviews with participants will also be carried out.

The focus group interviews at the MFC were conducted with two assistants who were also facilitators for the art and cultural program. At the classroom level, a focus group interview will be conducted by the principal investigator following the lessons to determine the impact of the program on students' understanding and perceptions of African art and culture.

Individualized interviews will be conducted by the researcher at the homes of the African-Canadian students and their parents, and at the work places of the teachers and the MFC staff. All the seven lessons were videotaped with the consent of parents and the students. Similarly, the interview sessions will be audiotaped and transcribed for analysis. So far, one focus group discussion session and eleven individualized interviews have been conducted. Currently, I am still in the process of collecting, transcribing and analyzing data. It is my hope that, at completion, this study will provide insights on the area of multicultural art education with specific reference to the cultural education of African-Canadian children.

Marilyn Zurmuehlen's Working Papers In Art Education 1998-1999 


\section{Significance of the Study}

This research is significant in that it provides an example of how educators can integrate the art, literature, history, culture, language, resistance and philosophy of the peoples who have been left in the margins of the curricula. It will look beyond current curriculum practices with a top-down approach, to the exciting and innovative grassroots model of partnership among the community, family, and school in the delivery of multicultural education. Top down policy that dictates classroom action often undermines teachers' personal sensibilities and their professional autonomy (Solomon \& Levine-Rasky, 1994). Collaboration in multicultural education will enable parents and other stakeholders to have some input on what their children learn. By having a choice, parents become more committed to the school than they would be, had the school and curriculum been assigned. These insights present serious implications not only for art education but for multicultural education as a whole. They call for schools and educators to reexamine current approaches to multicultural education, and be receptive to alternative non-hegemonic approaches both within and beyond academia that may contribute to a more comprehensive and equitable education.

\section{References}

Abarry, A. S. (1990). Afrocentricity: introduction. Journal of Black Studies 21(2): $123-125$.

Akbar, N. (1984). Africentric social sciences for human liberation. Journal of Black Studies 14 (4): 395-414.

Asante, M. K. (1987). The Africentric idea. Philadelphia: Temple University Press.

Asante, M. K. (1988). Afrocentricity. Trenton, NJ.: Africa World Press Inc.

Asante, M. K. (1990). Kemet, Afrocentricity and Knowledge.

Trenton, NJ: Africa World Press Inc.

Asante, M. K. (1991). The Africentric idea in education. Journal of Negro Education 60 (2): 170-180.

Banks, J. (1992). Multicultural education: For freedom's sake. Educational Leadership 49 (4), 32-36.

Bell, Y. R., Bouie, C. L., \& Baldwin, J. A. (1990). Africentric cultural consciousness and African-American male-female relationships. Journal of Black Studies 21(2): 162-189.

Bereiter, C., \& Englemann, S. (1966). Teaching Disadvantaged Children in the Preschool. Englewood Cliffs, NJ: Prentice-Hall.

Bopp, J., \& Bopp, M. (1985). Taking Time to Listen: Using CommunityBased Research to Build Programs. Lethbridge, Alberta: University of Lethbridge Four Worlds Development Press.

Marilyn Zurmuehlen's Working Papers In Art Education 1998-1999 
Chalmers, F. G. (1996). Celebrating Pluralism: Art, Education and Cultural Diversity. Los Angeles: The Getty Educational Institute for the Arts.

Dei, G. J. S. (1996). Anti-Racism Education: Theory and Practice. Ferwood Publishing, Halifax.

DePillars, M. N. (1990). Multiculturalism in visual arts education: Are America's educational institutions ready for multiculturalism? In B. Young (ed.), Art, Culture, and Ethnicity. Reston: National Art Education Association.

Diop, C. A. (1974). The African Origin of Civilization: Myth or Reality. New York: L. Hill.

Irwin, R., \& Farrell, R. (1996). The framing of Aboriginal art, In D. A. Long and O. P. Dickson (eds.), Visions of the Heart: Canadian

Aboriginal Issues. Toronto: Harcourt Brace.

McLeod, K. A. (1993). Multicultural Education: The State of the Art Study Report \#1. Canadian Association of Second Language Teachers: University of Toronto.

Moodley, K. A. (1995). Multicultural education in Canada: Historical development and current status, In J. A. Banks, \& C. A. Banks, (Eds.), Handbook of research in multicultural education. New York: Prentice Hall.

Neperud, R., Serlin, R., \& Jenkins, H. (1986). Ethnic aesthetics: The meaning of ethnic art for Blacks and non-Blacks. Studies in Art Education 28 (1), 16-29.

Nieto, S. (1996). Affirming Diversity: The Sociopolitical Context of Multicultural Education. USA: Longman Publishers.

Ogbu, J. U. (1986). The consequences of the American caste system, In The school Achievement of Minority Children: New Perspectives Ulric Neisser (ed), Hillsdale: Erlbaum.

Schiele, J. H. (1991). Afrocentricity for all Black Issues in Higher Education 8 (15), 27.

Schiele, J. H. (1994). Afrocentricity: implications for higher education. Journal of Black Studies 25(2), 150-169.

Solomon, R. P., \& Levine-Rasky, C. (1996). When principle meets practice: Teacher's contradictory responses to antiracist education. Alberta Journal of Educational Research 42 (1), 19-33.

Stull, D. D., \& J. Schensul Jr. (eds.). (1987). Collaborative Research and Social Change. Boulder: Westview Press.

Marilyn Zurmuehlen's Working Papers In Art Education 1998-1999 